Finally, it is shown that dislocation glide is the only mode of deformation in polar ice.

\section{REFERENCES}

Arzt, E., M.F. Ashby, and K.E. Easterling. 1983. Practical applications of hot-isostatic pressing diagrams: four case studies. Metall. Trans., 14A(2), 211-221.

Gow, A.J. 1968. Bubbles and bubble pressures in Antarctic glacier ice. J. Glaciol., 7(50), 167-182.

Jezek, K.C., R.B. Alley, and R.H. Thomas. 1985. Rheology of glacier ice. Science, 227(4692), 1335-1337.
Pimienta, P. and P. Duval. 1987. Rate controlling processes in the creep of polar glacier ice. J. Phys. (Paris), 48, Colloq. C1, 243-248. (Suppl. au 3.)

Pimienta, P., P. Duval, and V. Ya. Lipenkov. 1987. Mechanical behavior of anisotropic polar ice. International Association of Hydrological Sciences Publication 170 (Symposium at Vancouver 1987 - The Physical Basis of Ice Sheet Modelling), 57-66.

Wilson, C.J.L. 1986. Deformation induced recrystallization of ice: the application of in situ experiments. In Hobbs, B.E. and H.C. Heard, eds. Mineral and rock deformation: laboratory studies. Washington, DC, American Geophysical Union, 213-232. (Geophys. Monogr. 36.)

\title{
SURFACE STRAIN-RATES, BYRD GLACIER, ANTARCTICA
}

\section{(Abstract)}

by

John P. Scofield,

(Department of Geological Sciences, University of Maine, Orono, ME 04469, U.S.A.)

Dean R. Lindstrom,

(Department of Geophysical Sciences, University of Chicago, Chicago, IL 60637, U.S.A.)

and

Terence J. Hughes

(Department of Geological Sciences and Institute for Quaternary Studies, University of Maine, Orono, ME 04469, U.S.A.)

A least-squares solution utilizing photogrammetrically determined surface-velocity vectors (Brecher, 1982) was used to compute contour maps of surface strain-rate components on Byrd Glacier. On a broad scale, the results suggest longitudinal extensive flow in the region between 40 and $10 \mathrm{~km}$ above the grounding zone, laminar flow in the vicinity of the grounding zone, and longitudinal compressive flow in the region between 10 and $50 \mathrm{~km}$ below the grounding zone where flow diverges and enters the Ross Ice Shelf. More localized gradients of longitudinal, transverse, and shear strain-rate suggest that flow is influenced by bedrock topography. Strain-rates along a longitudinal ice-thickness profile above the grounding zone support this contention. Relative extension in the transverse and longitudinal directions correlates well in two locations with bedrock highs and increased surface slope, while compression in the transverse and longitudinal directions correlates with a bedrock low and a decrease in the surface slope in another location.

\section{REFERENCE}

Brecher, H.H. 1982. Photographic determination of surface velocities and elevations on Byrd Glacier. Antarct. J. U.S., 17(5), 79-81.

\section{ELECTRICAL RESISTIVITY SOUNDING RELATED TO ICE-CRYSTAL SIZE: A TECHNIQUE FOR PROBING THE HOLOCENE-WISCONSIN BOUNDARY}

\author{
(Abstract) \\ by \\ Sion Shabtaie and Charles R. Bentley \\ (Geophysical and Polar Research Center, University of Wisconsin-Madison, 1215 West Dayton Street, \\ Madison, WI 53706-1692, U.S.A.)
}

The depth of any know time horizon in an ice sheet is a valuable datum against which to check models of surface mass balance and ice dynamics. Where deep cores have been collected, the Holocene/Wisconsin climatic boundary (about 12000 B.P.) can be identified by changes in a large number of physical and chemical parameters. Unfortunately, there are only a few deep bore holes in the polar regions so other methods, such as geophysical techniques, are needed. One potentially powerful technique is electrical resistivity sounding. The resistivity of polar ice is strongly dependent on temperature, and several physical and chemical properties in the ice. By measuring the apparent resistivity of the ice 
sheet along a surface profile, a model of resistivity versus depth can be obtained. The measurements and model studies at several locations in Antarctica (Ice Stream B, Ross Ice Shelf, and Dome C) have resulted in the discovery of a rather sharp change in resistivity at a depth identified with the Holocene/Wisconsin transition at two locations (J9 on the Ross Ice Shelf and Dome C in East Antarctica), where core studies have been made.

The change in resistivity in polar ice sheets can be attributed primarily to changes in crystal size. In general, crystal size increases with depth down to the transition zone, decreases rather sharply over a short depth, and then gradually increases again. Resistivities show a similar behavior, and indeed there is a good correlation between the two at Dome C and J9. At a location on Ice Stream B where the ice is about $1060 \mathrm{~m}$ thick, our best model, using that correlation, shows the Holocene-Wisconsin boundary at $750 \mathrm{~m}$ depth. Furthermore, the shape of the resistivity change with depth (after correction for temperature) shows a good correlation with the crystal-size profile across that boundary at Byrd Station.

Another pronounced increase in resistivity occurs deeper in the ice, especially at locations on the Ross Ice Shelf where the ice has come from West Antarctic ice streams or the major outlet glaciers of East Antarctica. We attribute this increase also to a large increase in crystal size, such as occurs in the basal ice at Byrd Station, up-stream from Ice Stream D, and at Little America Station V on the Ross Ice Shelf.

\title{
GROUNDING-LINE RETREAT OF ICE STREAM B, ANTARCTICA
}

\section{(Abstract)}

\author{
by
}

Sion Shabtaie, Donald G. Schultz, and Charles R. Bentley

(Geophysical and Polar Research Center, University of Wisconsin-Madison, 1215 West Dayton Street, Madison, WI 53706-1692, U.S.A.)

\begin{abstract}
A comparison of data recently obtained on the "ice plain" of Ice Stream B with data collected on an International Geophysical Year (IGY) traverse suggests that between 1958 and 1984 the ice-stream grounding line retreated at an average rate of $0.8 \mathrm{~km} /$ year.

An IGY traverse, led by A.P. Crary in January 1958, crossed what we (Shabtaie and Bentley, 1987) now know to be the ice-stream grounding line near $83^{\circ} 23^{\prime} \mathrm{S}, 163^{\circ} 24^{\prime} \mathrm{E}$ On that traverse, surface elevations were carefully measured by barometric altimetry (Crary and others, 1962). Comparison with elevations on the floating ice of the Ross Ice Shelf recently determined by satellite altimetry (Shabtaie and Bentley, 1987) shows that the IGY traverse elevations were accurate within about $\pm 3 \mathrm{~m}$. Between traverse stations 28.11 and 29, Crary and others (1962) showed a pronounced surface-elevation drop of more than $30 \mathrm{~m}$. Although Crary and others (1962) believed, on the basis of seismic measurements, that all the ice was afloat, recent satellite determinations show that the higher-standing ice is grounded (Shabtaie and Bentley, 1987).

The recent position of the grounding line can be determined within a few kilometers from data collected on radar-sounding flights in December 1984 and December 1985, specifically surface elevations compared with ice thicknesses, and changes in ice-bottom reflection characteristics. The position of the grounding line on Crary's traverse can then be estimated to within a few kilometers by comparison of both absolute elevations and surface slopes
\end{abstract}

between the old and new profiles. That position for the 1958 grounding line is supported by the traverse log (Crary and others, 1962), which shows it to be the limit north of which crevasses were no longer encountered. The old and new positions of the grounding line are separated by $22 \pm 5 \mathrm{~km}$.

Changing surface elevations show a similar behavior. The ice surface is now lower by an amount that varies from no more than a few meters on the floating ice distant from the grounding line to $10-20 \mathrm{~m}$ on the grounded ice. In particular, absolute elevations at a station near the grounding line, where the ice was grounded throughout the 1958-85 period, show a drop of $15 \pm 8 \mathrm{~m}$. That decrease is consistent with the calculation by Shabtaie and Bentley (1987) for the "ice plain" of Ice Stream B: $0.39 \pm 0.29 \mathrm{~m}$ year. We conclude that there has been a regional thinning of the ice on the order of $0.6 \mathrm{~m} /$ year over the last three decades.

\section{REFERENCES}

Crary, A.P., E.S. Robinson, H.F. Bennett, and W.W. Boyd, jr. 1962. Glaciological studies of the Ross Ice Shelf, Antarctica, 1957-60. IGY Glaciol. Rep. 6.

Shabtaie, S. and C.R. Bentley. 1987. West Antarctic ice streams draining into the Ross Ice Shelf: configuration and mass balance. J. Geophys. Res., 92(B2), 1311-1336. 